\title{
The effects of increasing amounts of milk replacer powder added to whole milk on mammary gland measurements using ultrasound in dairy heifers
}

\author{
P. M. Furini, ${ }^{*}$ R. A. Azevedo, ${ }^{*}$ S. R. A. Rufino, ${ }^{*}$ F. S. Machado, $\dagger$ M. M. Campos, $\dagger$ L. G. R. Pereira, $\dagger$ \\ T. R. Tomich,† B. C. Carvalho,† G. B. Santos, $\neq$ and S. G. Coelho*1 \\ *Department of Animal Science, School of Veterinary Medicine, Federal University of Minas Gerais, Minas Gerais, Brazil, $30161-970$ \\ †Embrapa Dairy Cattle, Minas Gerais, Brazil, 36038-330 \\ łDepartment of Animal Science, School of Veterinary Medicine, Federal Fluminense University, Rio de Janeiro, 24220-900, Brazil
}

\begin{abstract}
The aim of this study was to determine the effect of increasing total solids (TS) in the liquid diet during the preweaning phase on mammary gland development in dairy heifers. The increase in TS was obtained with the addition of milk replacer powder to whole milk. Crossbreed Holstein-Gyr heifers $(\mathrm{n}=60)$ were distributed in 4 treatments with different TS concentrations: $13.5 \%$ $(\mathrm{n}=15), 16.1 \%(\mathrm{n}=15), 18.2 \%(\mathrm{n}=15)$, and $20.4 \%$ $(\mathrm{n}=15)$. The liquid diets were provided from 5 to 55 d of age. From 56 to 59 d of age, the total amount of liquid feed was reduced by half. Heifers were weaned at $60 \mathrm{~d}$ and monitored until $90 \mathrm{~d}$ of age. Ultrasound mammary gland evaluations were performed weekly between 5 to 11 wk of age, using a B-mode ultrasound equipped with microconvex transducer at a frequency of $6 \mathrm{MHz}$. In those same weeks, the manual palpation of mammary parenchyma (PAR) was performed. Increased TS concentration of liquid diet during the preweaning period increased body weight of heifers, but did not alter PAR growth and the deposition of adipose tissue in the mammary gland evaluated by ultrasonography. The oval-shaped structure of PAR was altered after 2 mo of age. In the evaluated period, PAR growth was isometric with respect to the body growth rate. Palpation scoring of PAR had a strong correlation with the ultrasound evaluation of the PAR.
\end{abstract}

Key words: development, parenchymal area, palpation score

\section{INTRODUCTION}

The conventional calf-feeding program adopted on dairy farms consists of feeding $10 \%$ of BW of liquid feed (Raeth-Knight et al., 2009), and this practice is also

Received February 24, 2017.

Accepted August 29, 2017.

${ }^{1}$ Corresponding author: sandragesteiracoelho@gmail.com known to stimulate starter intake and promote early rumen development (Azevedo et al., 2016a). However, the performance and feed efficiency of this system are often associated with unsatisfactory results (Khan et al., 2007). In intensive calf-feeding, higher amounts of nutrients are provided by increasing the total volume of liquid feed (Silper et al., 2014; Leão et al., 2016; Rosenberger et al., 2017), by increasing TS in milk replacer (MR; Terré et al., 2009; Chapman et al., 2016; Hill et al., 2016), or by the addition of milk balancer (Glosson et al., 2015) or milk replacer powder (MRP; Azevedo et al., 2016a,b).

According to Sejrsen and Purup (1997) and Radcliff et al. (2000), high ADG rates before puberty (90-320 $\mathrm{kg}$ of BW) in Holstein heifers may negatively affect the development of the mammary gland, with consequent lower milk yield in the first lactation. Weller et al. (2016) reported an alteration in mammary development with increased nutrient intake in prepubertal Holstein-Gyr heifers, with gains from 0.5 to $1.0 \mathrm{~kg} / \mathrm{d}$. The consequence is an increase in body fat content and fat accumulation in mammary gland, which may compromise PAR growth in heifers; however, during the preweaning phase (before 2 mo of age), this same effect has not been reported (Daniels et al., 2009). Meyer et al. (2006) and Geiger et al. (2016a,b) reported greater mammary development in heifers submitted to intensive feeding programs. According to Brown et al. (2005), the increased growth rate before weaning seems to have positive effects on mammary gland growth, as the increase in nutrient supply at that age almost doubled the PAR mass of heifers. This demonstrates that the rapid growth until weaning is not detrimental to mammary gland development. In this way, the effects of the nutrition plan on mammary gland development seem to differ between preweaning and prepubertal period, which may be due to the low fat content of the young calf at birth.

Evaluation of mammary gland development (PAR and mammary fat pad) in heifers is usually done after slaughter (Brown et al., 2005; Geiger et al., 2016a,b; 
Weller et al., 2016). This technique does not allow for the monitoring the animal during its development and presents high costs, which limits the research. In this context, alternative and noninvasive methods to reduce time and cost of such analyzes become important. Ultrasonography is a widely used technique for assessing fat deposition in animal carcasses (Arnold et al., 1991), and it has been used to evaluate developmental characteristics and lesions of the mammary gland in dairy calves and heifers (Nishimura et al., 2011; Esselburn et al., 2015, Albino et al., 2017). Another alternative used to monitor the development of the mammary gland in dairy heifers is palpation scoring, which is easy, does not present a cost in its execution, but is a subjective technique (Esselburn et al., 2015).

The objective of our study was (1) to determine the effect of increasing TS of whole milk (WM) by the addition of MRP in the mammary gland development of dairy heifers from wk 5 to 11 of age, using ultrasonography; and (2) to evaluate the relationship between the weekly measurements of PAR growth using ultrasound with the manual palpation scoring. Our hypotheses were (1) heifers fed higher TS contents in a liquid diet would have greater PAR growth in relation to heifers fed lower TS concentrations; and (2) the palpation scoring may be an option to monitor PAR development in dairy heifers.

\section{MATERIALS AND METHODS}

The Ethics Committee of Embrapa Dairy Cattle, Brazil (protocol no. 06/2014), approved the study. The trial was conducted at the Embrapa Dairy Cattle Experimental Farm, located in Coronel Pacheco, Minas Gerais, Brazil.

\section{Animals, Housing, Management, and Performance}

Holstein-Gyr crossbred heifers $(\mathrm{n}=60)$ were used; their genetic composition was 5/8 or more Holstein and $3 / 8$ or less Gyr. These heifers were previously part of the study conducted by Azevedo et al. (2016a) to evaluate the effect of increasing solids concentration by the addition of MRP to WM on performance, intake, and health of heifers from 5 to $90 \mathrm{~d}$ of age. Detailed descriptions of the facilities, initial care, and dietary composition from preweaning (5-59 d of age) to postweaning (60-90 d of age) can be found in Azevedo et al. (2016a). One heifer (treatment $17.5 \%$ TS) was removed from the study in the last week of the postweaning period due to an accident that led to the fracture of its anterior right leg.

The animals were randomly distributed in 4 treatments after birth. Preweaning treatments consisted of increasing amounts of MRP (Sprayfo Violet SSP, Sloten BV, Deventer, the Netherlands; $20 \% \mathrm{CP}$ and $33 \%$ ether extract) added to $\mathrm{WM}(12.6 \pm 0.7 \% \mathrm{TS}$, mean $\pm \mathrm{SD}$; Table 1) to adjust the TS to expected concentrations of $12.5 \%$ (actual TS $=13.5 \pm 0.53 \% ; \mathrm{n}=15), 15.0 \%$ (actual TS $=16.1 \pm 0.03 \% ; \mathrm{n}=15), 17.5 \%$ (actual $\mathrm{TS}=$ $18.2 \pm 0.14 \% ; \mathrm{n}=13$ ), and $20.0 \%$ (actual TS $=20.4 \pm$ $0.24 \% ; \mathrm{n}=15)$. The initial TS content in the $\mathrm{WM}$ was measured daily, immediately after milking and before each feeding, using a Brix refractometer (DD-3 Palm Abbe Digital, Misco, Solon, OH). Brix grade values were converted to TS content using the equation proposed by Moore et al. $(2009)$ [TS $=0.9984 \times($ Brix refractometer reading) +2.077 ] and the amount of MRP to be added to the WM was adjusted to achieve the desired TS content for each treatment. The MRP was added to the WM immediately before feeding the heifers. The total volume of treatment $(6 \mathrm{~L} / \mathrm{d})$ was divided into 2 equal meals (0800 and $1600 \mathrm{~h}$ ) and provided to heifers in buckets from 5 to $55 \mathrm{~d}$ of age. At $56 \mathrm{~d}$ of age, the total volume of liquid feed was reduced by half (3 $\mathrm{L} / \mathrm{d}$, provided at $0800 \mathrm{~h}$ only) and heifers were weaned at $60 \mathrm{~d}$ of age. Starter (Soylac Rumen 20\% Flocculated, Total Alimentos, Três Corações, Brazil) and water were offered ad libitum during the preweaning period. At $70 \mathrm{~d}$ of age, corn silage was included ad libitum in a separate bucket.

\section{Mammary Ultrasound}

Ultrasound images were obtained weekly between wk 5 to 11 of age, always by the same evaluator, using a B-mode ultrasound equipped with microconvex transducer at a frequency of $6 \mathrm{MHz}$ (DP 2200, Mindray, Shenzhen, China). For the evaluation of the mammary glands (front and rear quarters), the animals were laid on lateral decubitus with the probe in a standardized position at a $45^{\circ}$ inclination in relation to the teat position, always in caudal-cranial direction (Nishimura et al., 2011). To increase the contact of the probe with the skin and to improve the visualization of the images, the area to be evaluated was wetted with $70 \%$ alcohol and the ultrasound gel was placed (Carbogel ULT, Sao Paulo, Brazil).

The images obtained were saved in BMP format and then transferred to the ImageJ program (National Institutes of Health; https://imagej.nih.gov/ij/docs/ guide/user-guide.pdf) for further analysis. In ImageJ, the scale of pixels per centimeter $\left(1 \mathrm{~cm}^{2}=48,148\right.$ pixels) was calibrated using the straight tracer, and PAR areas were resultant by tracing the PAR area with the mouse and cursor using the freehand tracer.

Within in PAR area, we used number the pixels to calculate the average pixel brightness. In 8-bit images, 
each pixel was numerically represented on a scale of 256,000 shades of gray $(0=$ black; $255,000=$ white $)$ according to their brightness (Ferreira and Rasband. 2011). According to Albino et al. (2015), structures with a high ability to reflect sound waves (fat tissue) are hyperechoic and thus present with a higher pixel value. Conversely, tissues with a limited ability to reflect sound waves are hypoechoic and have a lower pixels value (PAR tissue). The circularity was evaluated using $\left[4 \pi \times(\text { area/perimeter })^{2}\right]$ obtained in ImageJ and it ranges from 0 (infinitely elongated polygon) to 1 (perfect circle; National Institutes of Health, Bethesda, MD).

\section{Palpation Scoring}

Manual palpation of PAR was performed before all ultrasound evaluations, by a single evaluator, adapting the methodology of scoring proposed by Esselburn et al. (2015) and scored as (1) small and threadlike, comparable to a small grain of rice; (2) a larger grain of rice; (3) a small pea; (4) a chickpea; (5) almond sized; (6) larger than an almond; and (7) a whole pecan. For all variables, the averages of the front and rear glands were obtained.

\section{Statistical Analysis}

Data were analyzed using SAS version 9.0 (SAS Institute Inc., Cary, NC). The variables were analyzed using a repeated-measures mixed model (PROC MIXED), including heifer as a random effect and treatment, week, block (genetic group), mammary gland (front or rear), and their interaction as fixed components. Differences among treatments were assessed using orthogonal polynomial contrasts to estimate the linear, quadratic, and cubic effects of increasing TS concentrations of liquid feed. Circularity differences of the mammary gland (front and rear) and differences between genetic groups were analyzed, including mammary gland or genetic group as a fixed effect and using a Tukey adjustment for $P$-values. Palpation scores by period were tested as a nonparametric variable using the Kruskal-Wallis test with $95 \%$ confidence intervals for treatment comparisons (PROC NPAR1WAY). Least squares means for each treatment are reported. BW at birth was considered as a covariate. Significance was declared at $P \leq$ 0.05 .

\section{RESULTS AND DISCUSSION}

According to Azevedo et al. (2016a), the difference between the TS content initially proposed and the values found by laboratory analysis may have occurred because the equation used to convert Brix grade values to TS content was designed based on waste milk samples (Moore et al., 2009), which are different from the WM used in this experiment. A linear increase $(P \leq 0.05)$ in BW (kg) was observed according to the increase in TS levels of liquid diet between 5 to 11 wk of age (Table $2)$. As predicted, the total intake of $\mathrm{CP}(\mathrm{g} / \mathrm{d})$ and gross energy (Mcal $/ \mathrm{kg}$ ) increased linearly (Azevedo et al., 2016a) with the concentration of TS. This increasing during the preweaning phase boosted the development

Table 1. Nutrient composition (DM basis, \% unless otherwise noted) of whole milk (WM), milk replacer powder (MRP), starter, corn silage, and treatments

\begin{tabular}{|c|c|c|c|c|c|c|c|c|}
\hline \multirow[b]{2}{*}{ Item } & \multirow[b]{2}{*}{ WM } & \multirow[b]{2}{*}{$\mathrm{MRP}^{1}$} & \multirow[b]{2}{*}{ Starter } & \multirow{2}{*}{$\begin{array}{l}\text { Corn } \\
\text { silage }\end{array}$} & \multicolumn{4}{|c|}{ Treatment (\% TS in WM) } \\
\hline & & & & & 13.5 & 16.1 & 18.2 & 20.4 \\
\hline$\overline{\mathrm{DM}^{2}}$ & 12.6 & 94.7 & 89.3 & 31.7 & 13.5 & 16.1 & 18.2 & 20.4 \\
\hline $\mathrm{CP}$ & 25.6 & 20.0 & 21.2 & 6.7 & 25.2 & 23.8 & 23.2 & 22.9 \\
\hline Ether extract & 33.0 & 13.4 & 2.1 & 3.6 & 33.0 & 28.6 & 26.0 & 23.7 \\
\hline Ash & - & 7.3 & 11.9 & 5.8 & 5.8 & 5.6 & 5.5 & 5.3 \\
\hline NDF & - & - & 23.5 & 56.7 & - & - & - & - \\
\hline $\mathrm{ADF}$ & - & - & 10.1 & 28.6 & - & - & - & - \\
\hline Gross energy (Mcal/kg) & - & 4.5 & 3.7 & 4.1 & 5.8 & 5.7 & 5.6 & 5.6 \\
\hline Lactose $^{3}$ & 33.9 & 47.0 & - & - & 31.5 & 39.6 & 42.5 & 44.8 \\
\hline Calcium & - & 1.1 & 1.5 & 0.2 & 1.1 & 1.0 & 1.0 & 1.0 \\
\hline Phosphorus & - & 0.5 & 0.5 & 0.2 & 0.8 & 0.8 & 0.7 & 0.7 \\
\hline Magnesium & - & 0.1 & 0.3 & 0.2 & 0.1 & 0.1 & 0.1 & 0.1 \\
\hline
\end{tabular}

${ }^{1}$ Basic composition: whey, lactose-free whey, lipids of plant origin, wheat gluten hydrolyzate, folic acid, nicotinic acid, pantothenic acid, betaine, biotin, iron oxide, magnesium oxide, zinc oxide, sodium selenite, copper sulfate, manganese sulfate, vitamin $A$, vitamin $B_{1}$, vitamin $B_{12}$, vitamin $B_{2}$, vitamin $B_{6}$, vitamin $C$, vitamin $D_{3}$, vitamin E, vitamin K, and probiotic additive (Enterococcus faecium and Lactobacillus rhamnosus).

${ }^{2}$ As-fed basis.

${ }^{3}$ Lactose $\%$ of treatments $=100-\mathrm{CP} \%-$ ether extract $\%-$ ash $\%-2($ Drackley, 2008). 


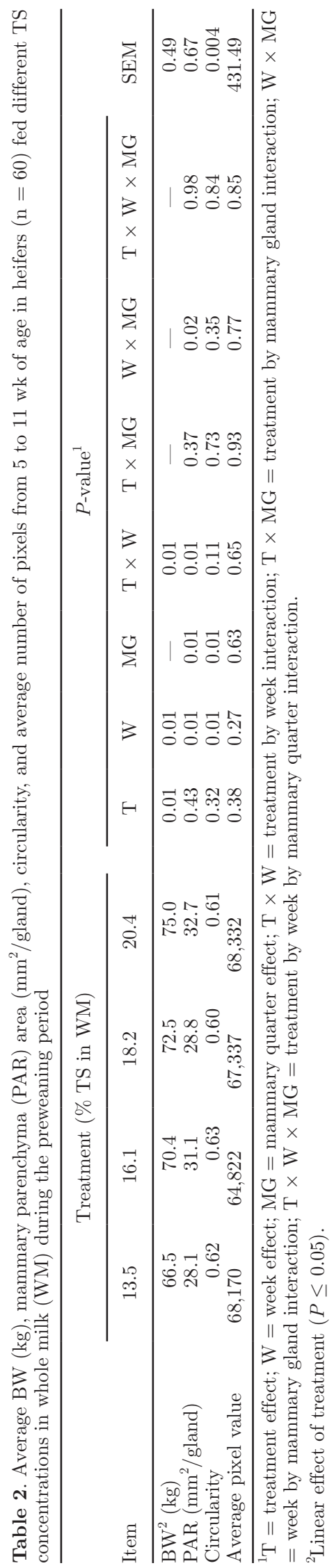

of the skeletal structure and the body tissues in heifers because of the higher protein and energy intake; Glosson et al. (2015) reported similar results.

\section{Mammary Ultrasound}

Interaction $(P \leq 0.05$; Table 2$)$ between the TS concentrations and the evaluated periods for PAR area $\left(\mathrm{mm}^{2} /\right.$ gland $)$ was observed. At $5 \mathrm{wk}$ of age, the lower mammary PAR area was observed for the concentration of $17 \%$ TS of liquid diet (quadratic, $P=0.03$; Table 3 ). At wk 11, when the animals were already weaned, we found an increase (linear, $P=0.02$; Table 3 ) in PAR area according to the increase of TS concentrations of liquid diet. This result is similar to that observed for the weight gain and appears to be result of better nutrition during the preweaning period, as a consequence for the increasing linear in the total $\mathrm{CP}(\mathrm{g} / \mathrm{d})$ and gross energy intake (Mcal $/ \mathrm{kg}$ ) according to the increase of TS concentrations in the liquid diets (Azevedo et al., 2016a).

According to Brown et al. (2005), the increase in CP and energy intake between 2 to 8 wk of age increased PAR growth rate of heifers, as well as the DNA and RNA concentrations, suggesting that rapid growth is not harmful when the intraparenchymal fat content is not increased. On the other hand, Esselburn et al. (2015) did not observe dietary effect on the area and composition of the PAR until 8 wk of age in heifers fed 3 sources of fat in MR.

Interaction between PAR area and evaluated weeks $(P \leq 0.05$; Table 2$)$ was observed. At 11 wk of age, the PAR of the rear $\left(61.1 \mathrm{~mm}^{2} /\right.$ gland $)$ quarters was $12.4 \%$ higher compared with the front $\left(53.5 \mathrm{~mm}^{2} /\right.$ gland $)$ quarters $(P=0.05$; Table 4$)$. In adult animals, the front quarters are smaller than the rear glands, with a ratio of 41:59 (Ayadi et al., 2003). For our study, the ratio between the PAR area of the front and rear glands was 47:53, which is similar to that observed by Esselburn et al. (2015).

At 5 wk of age, the PAR area and BW of heifers, regardless of the treatments, were $11.4 \pm 4.6 \mathrm{~mm}^{2}$ and $53.7 \pm 4.6 \mathrm{~kg}$, increasing to $28.8 \pm 9.3 \mathrm{~mm}^{2}$ and $73.3 \pm$ $4.6 \mathrm{~kg}$, respectively, at $8 \mathrm{wk}$ of age. These results show that PAR increased 2.5 times and BW 1.4 times during this period. Likewise, a mammary growth rate of 1.8 was observed in relation to the BW growth rate, which indicates a slightly higher growth rate compared with the reported by Sinha and Tucker (1969) and Meyer et al. (2006) as an isometric growth (1.5 times). On the other hand, Esselburn et al. (2015) reported that before 2 mo of age, the PAR growth is allometric with respect to the $\mathrm{BW}$ in Holstein heifers, and the dogmatic assumption that PAR growth is isometric dur- 
Table 3. Interaction between treatment and week for mammary parenchyma area $\left(\mathrm{mm}^{2}\right)$ in heifers $(\mathrm{n}=60)$ fed different TS concentrations in whole milk (WM) during the preweaning period

\begin{tabular}{|c|c|c|c|c|c|c|c|}
\hline \multirow[b]{2}{*}{ Week } & \multicolumn{4}{|c|}{ Treatment (\% TS in WM) } & \multirow[b]{2}{*}{ SEM } & \multicolumn{2}{|c|}{ Contrast, $P$-value } \\
\hline & 13.5 & 16.1 & 18.2 & 20.4 & & Linear & Quadratic \\
\hline 5 & 12.1 & 10.7 & 10.2 & 12.5 & 0.42 & 0.79 & 0.03 \\
\hline 6 & 16.6 & 14.7 & 15.2 & 17.7 & 0.68 & 0.52 & 0.11 \\
\hline 7 & 25.0 & 23.8 & 21.1 & 26.6 & 1.05 & 0.81 & 0.11 \\
\hline 8 & 26.9 & 28.1 & 27.0 & 31.1 & 0.90 & 0.17 & 0.41 \\
\hline 9 & 30.3 & 31.8 & 31.2 & 35.8 & 1.00 & 0.08 & 0.43 \\
\hline 10 & 37.7 & 45.1 & 41.0 & 41.5 & 1.36 & 0.56 & 0.20 \\
\hline 11 & 47.5 & 62.0 & 55.2 & 63.1 & 1.95 & 0.02 & 0.40 \\
\hline
\end{tabular}

ing this time is not valid. The differences observed for mammary growth between the present study and the results verified for Esselburn et al. (2015) can possibly be explained by the different genetic compositions and different calf-feeding strategies evaluated. Therefore, more research is needed to determine the influence of genetics and calf-feeding strategies on PAR growth in dairy heifers.

In the postweaning period (between 8-11 wk of age), the PAR area and BW of heifers, regardless of the treatments, were $28.8 \pm 9.3 \mathrm{~mm}^{2}$ and $73.3 \pm 4.6 \mathrm{~kg}$, increasing to $40.9 \pm 20.6 \mathrm{~mm}^{2}$ and $82.0 \pm 10.5 \mathrm{~kg}$, respectively, at 8 and 11 wk of age. The mammary growth rate of 1.7 was observed in relation to the BW growth rate, demonstrating that the animals were still in a growth phase slightly higher than that reported by Sinha and Tucker (1969) and Meyer et al. (2006) as isometric.

According to Nishimura et al. (2011), at 2 mo of age, the mammary gland is an oval hyperechoic structure. The loss of delimitation and shape of the PAR, as well as reduction of echogenicity in ultrasound images, occurs after this period. The oval-shaped PAR structure was similar between the different treatments (Table 2). However, the rear glands were more circular than the

Table 4. Interaction between mammary gland and week for mammary parenchyma area $\left(\mathrm{mm}^{2} /\right.$ gland $)$ in heifers $(\mathrm{n}=60)$ fed different TS concentrations in whole milk during the preweaning period

\begin{tabular}{lccc}
\hline & \multicolumn{2}{c}{ Mammary gland } & \\
\cline { 2 - 3 } Week & Front & Rear & $P$-value \\
\hline 5 & 11.3 & 11.5 & 0.84 \\
6 & 16.3 & 15.8 & 0.72 \\
7 & 23.8 & 24.4 & 0.76 \\
8 & 27.4 & 29.0 & 0.37 \\
9 & 31.0 & 33.5 & 0.21 \\
10 & 40.2 & 42.7 & 0.34 \\
11 & $53.5^{\mathrm{b}}$ & $61.1^{\mathrm{a}}$ & 0.05 \\
\hline
\end{tabular}

$\overline{\mathrm{a}, \mathrm{b}}$ Means with different superscripts (in rows) differ by Tukey test $(P$ $<0.05)$. front quarters $(P \leq 0.05$, quadratic effect), with the greater circularity observed at $8 \mathrm{wk}$ of age (Figure 1 ). Conversely, Nishimura et al. (2011) did not verify differences between the ultrasound images between the front and rear glands.

No influence of the TS concentration of the liquid diet was observed on the mean number of pixels in the heifer PAR area (Table 2). According to Albino et al. (2015), the echogenicity is defined by the number of pixels; that is, structures with high capacity to reflect sound waves are hyperechoic and with more pixels (adipose tissue). On the other hand, structures with limited capacity to reflect sound waves are hypoechogenic and have fewer pixels (PAR). Therefore, it is reasonable to assume that the increase in TS concentrations of liquid diets up to $20.4 \%$ did not influence the deposition of fat in the mammary gland. These results, combined with that observed by Azevedo et al. (2016b), who reported

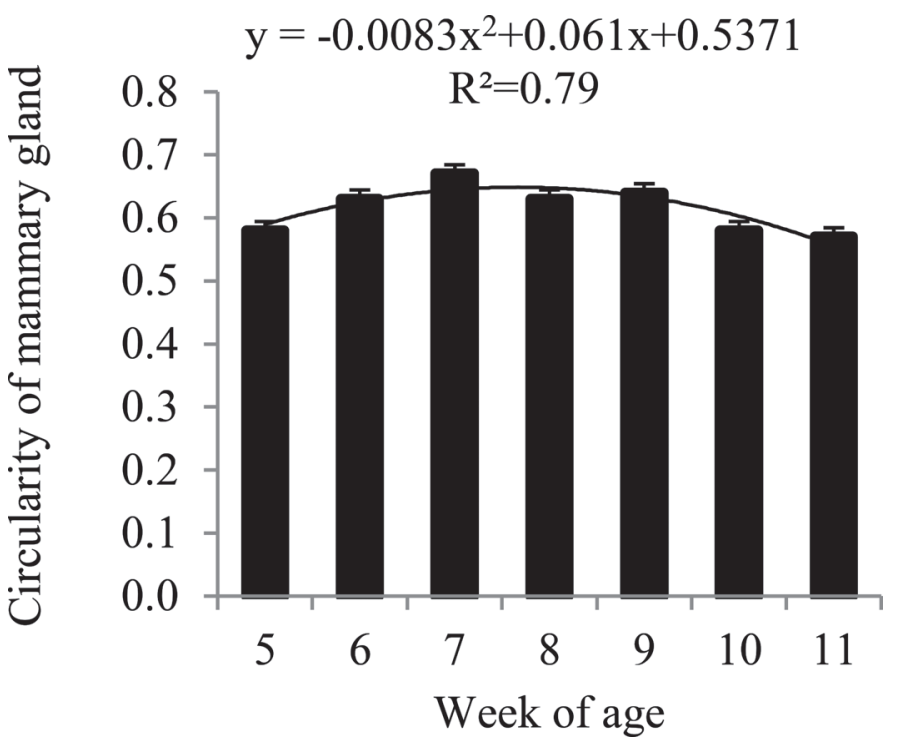

Figure 1. Circularity of mammary gland in heifers fed different TS concentrations $(13.5,16.1,18.2$, and $20.4 \%$ ) in whole milk during the preweaning period. Error bars represent SE. 
Table 5. Average palpation scores in heifers $(n=60)$ fed different TS concentrations in whole milk $(\mathrm{WM})$ during the preweaning period

\begin{tabular}{|c|c|c|c|c|c|c|}
\hline \multirow[b]{2}{*}{ Week } & \multicolumn{4}{|c|}{ Treatment (\% TS in WM) } & \multirow[b]{2}{*}{$P$-value } & \multirow[b]{2}{*}{ SEM } \\
\hline & 13.50 & 16.10 & 18.20 & 20.40 & & \\
\hline 5 & 2.4 & 2.2 & 2.4 & 2.6 & 0.47 & 0.09 \\
\hline 6 & 2.9 & 2.8 & 2.9 & 3.1 & 0.63 & 0.10 \\
\hline 7 & 3.6 & 3.7 & 3.5 & 3.8 & 0.88 & 0.10 \\
\hline 8 & 3.6 & 4.0 & 3.8 & 4.4 & 0.09 & 0.09 \\
\hline 9 & 4.2 & 4.0 & 4.3 & 4.6 & 0.26 & 0.10 \\
\hline 10 & 4.3 & 4.9 & 4.6 & 4.9 & 0.16 & 0.09 \\
\hline 11 & 4.8 & 5.4 & 5.3 & 5.3 & 0.16 & 0.10 \\
\hline
\end{tabular}

no change in body composition of male calves fed diets with TS concentrations, similar to those of the present study, support the hypothesis that the same was true for body composition and heifer mammary gland. Other studies demonstrated similar results. Esselburn et al. (2015) found no dietary influence on the lipid composition of the breast fat pad of DM fed heifers with different sources and amounts of fat. Brown et al. (2005) concluded that high energy and protein intake in heifers during the preweaning phase does not increase fat deposition in PAR. On the other hand, Geiger et al. (2016b) observed that the amount of DNA in the breast fat pad was 5.4 times greater, as well as the fat concentration, for heifers $(1.13 \mathrm{~kg} / \mathrm{d}$ of $\mathrm{MR})$ than the restricted heifers $(0.45 \mathrm{~kg} / \mathrm{d}$ of MR). However, in the study of Geiger et al. (2016b), fat concentration and amount of total fat in PAR were not affected by different calf-feeding strategies.

\section{Palpation Scores}

The palpation score of PAR did not differ between the TS concentrations supplied during the preweaning phase in any of the evaluated weeks (Table 5), ranging from $2.4 \pm 1.0$ in wk 5 and $5.2 \pm 1.1$ in wk 11 . The correlation observed between the palpation score of mammary parenchyma and the measurements of mammary parenchyma area $\left(\mathrm{mm}^{2} /\right.$ gland $)$ using ultrasound was positive $\left(\mathrm{R}^{2}=0.71, P \leq 0.01\right)$ and moderate, and similar to that reported by Esselburn et al. (2015), which was 0.68 between ultrasound measurements and palpation scoring in wk 2 to 8 of age. This correlation indicates that the palpation score of PAR, although subjective, may be a useful and low-cost tool for monitoring PAR development and may be used to select animals with better potential for milk production without the use of ultrasound, even in the initial stages of animal life. However, more studies proving and establishing a guide on how to obtain and analyze this variable are needed.

\section{CONCLUSIONS}

Increasing the concentration of TS in liquid feed up to $20.4 \%$ until 8 wk of age did not affect PAR development and adipose deposition in the mammary gland when evaluated using ultrasonography. At 11 wk of age, a linear increase in PAR growth was observed according to the increased concentration of TS in liquid feed, without dietary influence on the other parameters. Between 5 to 11 wk of age, PAR growth was isometric with respect to heifer body growth. The circularity of the mammary gland was altered after 2 mo of age. Ultrasonography is a noninvasive technique for monitoring mammary gland development. However, further studies involving larger numbers of animals and different breeds are suggested to increase the accuracy of the technique. Palpation score and ultrasound evaluation were moderately correlated.

\section{ACKNOWLEDGMENTS}

The authors thank the Coordenação de Aperfeiçoamento de Pessoal de Nível Superior (CAPES, Brasília, Brazil), Fundação de Amparo à Pesquisa do Estado de Minas Gerais (FAPEMIG, Minas Gerais, Brazil), Conselho Nacional de Desenvolvimento Científico e Tecnológico (CNPq, Brasilia, DF, Brazil), and Embrapa Dairy Cattle (Minas Gerais, Brazil) for the financial support.

\section{REFERENCES}

Albino, R. L., S. E. F. Guimarães, K. M. Daniels, M. M. S. Fontes, A. F. Machado, G. B. Dos Santos, and M. I. Marcondes. 2017. Technical note: Mammary gland ultrasonography to evaluate mammary parenchymal composition in prepubertal heifers. J. Dairy Sci. 100:1588-1591.

Albino, R. L., M. I. Marcondes, R. M. Akers, E. Detmann, B. C. Carvalho, and T. E. Silva. 2015. Mammary gland development of dairy heifers fed diets containing increasing levels of metabolisable protein: Metabolisable energy. J. Dairy Res. 82:113-120. 
Arnold, J. W., J. K. Bertrand, L. L. Benyshek, and C. Ludwig. 1991. Estimates of genetic parameters for live animal ultrasound, actual carcass data, and growth traits in beef cattle. J. Anim. Sci. 69:985-992.

Ayadi, M., G. Caja, X. Such, and C. H. Knight. 2003. Use of ultrasonography to estimate cistern size and milk storage at different milking intervals in the udder of dairy cows. J. Dairy Res. 70:1-7.

Azevedo, R. A., F. S. Machado, M. M. Campos, P. M. Furini, S. R. A. Rufino, L. G. R. Pereira, T. R. Tomich, and S. G. Coelho. 2016a. The effects of increasing amounts of milk replacer powder added to whole milk on feed intake and performance in dairy heifers. J. Dairy Sci. 99:8018-8027.

Azevedo, R. A., F. S. Machado, M. M. Campos, D. R. G. Lopes, S. F. Costa, H. C. Mantovani, F. C. F. Lopes, M. I. Marcondes, L. G. R. Pereira, T. R. Tomich, and S. G. Coelho. 2016b. The effects of increasing amounts of milk replacer powder added to whole milk on passage rate, nutrient digestibility, ruminal development, and body composition in dairy calves. J. Dairy Sci. 99:8746-8758.

Brown, E. G., M. J. Vandehaar, K. M. Daniels, J. S. Liesman, L. T. Chapin, J. W. Forrest, R. M. Akers, R. E. Pearson, and M. S. Nielsen. 2005. Effect of increasing energy and protein intake on mammary development in heifer calves. J. Dairy Sci. 88:595-603.

Chapman, C. E., P. S. Erickson, J. D. Quigley, T. M. Hill, H. G. Bateman, F. X. Suarez-Mena, and R. L. Schlotterbeck. 2016. Effect of milk replacer program on calf performance and digestion of nutrients with age of the dairy calf. J. Dairy Sci. 99:2740-2747.

Daniels, K. M., M. L. McGilliard, M. J. Meyer, M. E. Van Amburgh, A. V. Capuco, and R. M. Akers. 2009. Effect of body weight and nutrition on histological mammary development in Holstein heifers. J. Dairy Sci. 92:499-505.

Drackley, J. K. 2008. Calf nutrition from birth to breeding. Vet. Clin. North Am. Food Anim. Pract. 24:55-86.

Esselburn, K. M., T. M. Hill, H. G. Bateman II, F. L. Fluharty, S. J. Moeller, K. M. O'Diam, and K. M. Daniels. 2015. Examination of weekly mammary parenchymal area by ultrasound, mammary mass, and composition in Holstein heifers reared on 1 of 3 diets from birth to 2 months of age. J. Dairy Sci. 98:5280-5293.

Ferreira, T., and W. S. Rasband. 2011. ImageJ User Guide - IJ 1.46. Accessed Dec. 5, 2016. http://imagej.nih.gov/ij/docs/index.html.

Geiger, A. J., C. L. M. Parsons, and R. M. Akers. 2016b. Feeding a higher plane of nutrition and providing exogenous estrogen increases mammary gland development in Holstein heifer calves. J. Dairy Sci. 99:7642-7653.

Geiger, A. J., C. L. M. Parsons, R. E. James, and R. M. Akers. 2016a. Growth, intake, and health of Holstein heifer calves fed an enhanced pre-weaning diet with or without exogenous estrogen. J. Dairy Sci. 99:3995-4004.

Glosson, K. M., B. A. Hopkins, S. P. Washburn, S. Davidson, G. Smith, T. Earleywine, and C. Ma. 2015. Effect of supplementing pasteurized milk balancer products to heat-treated whole milk on the growth and health of dairy calves. J. Dairy Sci. 98:1127-1135.

Hill, T. M., J. D. Quigley, F. X. Suarez-Mena, H. G. Bateman II, and R. L. Schlotterbeck. 2016. Effect of milk replacer feeding rate and functional fatty acids on dairy calf performance and digestion of nutrients. J. Dairy Sci. 99:6352-6361.
Khan, M. A., H. J. Lee, W. S. Lee, H. S. Kim, S. B. Kim, K. S. Ki, J. K. Ha, H. G. Lee, and Y. J. Choi. 2007. Pre- and post-weaning performance of Holstein female calves fed milk through stepdown and conventional methods. J. Dairy Sci. 90:876-885.

Leão, J. M., J. A. M. Lima, A. M. Q. Lana, H. M. Saturnino, R. B. Reis, F. A. Barbosa, R. A. Azevedo, R. V. Sá Fortes, and S. G. Coelho. 2016. Performance of crossbred heifers in different stepdown waste milk-feeding strategies. Trop. Anim. Health Prod. 48:1607-1612.

Meyer, M. J., A. V. Capuco, D. A. Ross, L. M. Lintault, and M. E. Van Amburgh. 2006. Developmental and nutritional regulation of the prepubertal bovine mammary gland: II. Epithelial cell proliferation, parenchymal accretion rate, and allometric growth. J. Dairy Sci. 89:4298-4304.

Moore, D. A., J. Taylor, M. L. Hartman, and W. M. Sischo. 2009. Quality assessments of waste milk at a calf ranch. J. Dairy Sci. 92:3503-3509.

Nishimura, M., T. Yoshida, S. El-Khodery, M. Miyoshi, J. Yasuda, and K. Miyahara. 2011. Ultrasound imaging of mammary glands in dairy heifers at different stages of growth. J. Vet. Med. Sci. $73: 19-24$

Radcliff, R. P., M. J. VandeHaar, L. T. Chapin, T. E. Pilbeam, D. K. Beede, E. P. Stanisiewski, and H. A. Tucker. 2000. Effects of diet and injection of bovine somatotropin on prepubertal growth and first-lactation milk yields of Holstein cows. J. Dairy Sci. 83:23-29.

Raeth-Knight, M., H. Chester-Jones, S. Hayes, J. Linn, R. Larson, D. Ziegler, B. Zeigler, and N. Broadwater. 2009. Impact of conventional or intensive milk replacer programs on Holstein heifer performance through six months of age and during first lactation. J. Dairy Sci. 92:799-809.

Rosenberger, K., J. H. C. Costa, H. W. Neave, M. A. G. von Keyserlingk, and D. M. Weary. 2017. The effect of milk allowance on behavior and weight gains in dairy calves. J. Dairy Sci. 100:504-512.

Sejrsen, K., and S. Purup. 1997. Influence of prepubertal feeding level on milk yield potential of dairy heifers: A Review. J. Anim. Sci. $75: 828-835$

Silper, B. F., A. M. Q. Lana, A. U. Carvalho, C. S. Ferreira, A. P. S. Franzoni, J. A. M. Lima, H. M. Saturnino, R. B. Reis, and S. G. Coelho. 2014. Effects of milk replacer feeding strategies on performance, ruminal development, and metabolism of dairy calves. J. Dairy Sci. 97:1016-1025.

Sinha, Y. N., and H. A. Tucker. 1969. Mammary development and pituitary prolactin level of heifers from birth through puberty and during the estrous cycle. J. Dairy Sci. 52:507-512.

Terré, M., C. Tejero, and A. Bach. 2009. Long-term effects on heifer performance of an enhanced growth feeding programme applied during the pre-weaning period. J. Dairy Res. 76:331-339.

Weller, M. M. D. C. A., R. L. Albino, M. I. Marcondes, W. Silva, K. M. Daniels, M. M. Campos, M. S. Duarte, M. L. Mescouto, F. F. Silva, and S. E. F. Guimaraes. 2016. Effects of nutrient intake level of same diet on mammary parenchyma growth and gene expression in crossbreed (Holstein x Gyr) prepubertal heifers. J. Dairy Sci. 99:9962-9973. 